\title{
ASPECTS REGARDING MONITORING OF THE PEST TUTA ABSOLUTA (TOMATO LEAF MINER) ON TOMATO CROPS UNDER HIGH PLASTIC TUNNELS AND EFFICACY OF SOME INSECTICIDES TESTED FOR ITS CONTROL
}

\author{
S. Hogea ${ }^{1 *}$ and M. Costache ${ }^{1}$ \\ 1 Research and Development Institute for Vegetables and Flower Growing, Vidra, \\ Ilfov, România \\ *Corresponding author: hogea.simona@yahoo.com
}

\section{ABSTRACT}

Tuta absoluta (Meyrick) (Lepidoptera: Gelechiidae) is a pest native from South America, which was first reported in Romania in 2009 (Satu Mare). Among the vegetable species, tomatoes are the main host of the pest, but can also be found on potato, black nightshade (Solanumnigrum), eggplant, bell peppers and tobacco.Yield losses caused by Tuta absoluta can reach $100 \%$, in the absence of adequate control measures.Pheromone traps are a complementary method of this pest control, contributing considerably to reducing its population. The experiments were done in 2020, in the area of influence of R.I.V.F.G. - Vidra, in the first cycle of crop, using the hybrids Sahmat F1 and Zadurella F1. The Delta traps with pheromone were placed in 2 high plastic tunnels with tomatoes, from 2 different locations (Dobreni and Vărăști) and the number of captured adults and the frequency and intensity of the attack on foliage and fruits were periodically recorded, between May and July. The number of captured adults on the sticky plate which have $397,75 \mathrm{~cm}^{2}$, ranged in time, between 52 and 482. Chemical treatments were also applied, at 7 daysintervals, to prevent the spread of the pest and limit the damage caused by it. The average yields obtained were between $6.950 \mathrm{~kg} / \mathrm{m}^{2}$ (farmer 1, Dobreni) and $8.270 \mathrm{~kg} / \mathrm{m}^{2}$ (farmer 2, Vărăști).

Keywors: attack, Delta trap, pheromone, treatments, yield

\section{INTRODUCTION}

Tuta absoluta (tomatoleafminer) is a pest native from South America that later spread to most tomato-growing countries.The pest has about 12 generations of adults per year (Mkonyi et al., 2020).

In Romania, was first reported in 2009, in the north part of the country (Satu Mare), and a year later the presence of this pest was reported in tomato crops in glasshousesaround Bucharest (Bratu et al., 2015).

The main method of control is the use of chemicals, but alternative, less polluting control methods have also been promoted, such as: microbiological control and biological control by releasing parasites and predators.Other complementary methods of control are the use of light traps and traps with asyntheticpheromones to annihilate males by disturbing mating.Using traps with synthetic pheromones, the ability of males to identify females is disturbed and implicitly the density of the pest population is considerably reduced (Cocco et al., 2012). 


\section{MATERIALS AND METHODS}

The experiments were done in 2020, in the first cycle of crop, at 2 farmers from Dobreni and Vărăștivillages, Giurgiu county, located in the area of influence of R.I.V.F.G. - Vidra, by placing Delta traps, with pheromones, in tomato crops from high plastic tunnels. In the first location, the hybrid used was Sahmat F1, a rustic hybrid of tomatoes, with undetermined growth, recommended for spring crops in glasshouses, high plastic tunnels, but also in the field, to obtain early harvests (www.marcoser.ro), and in the second location was planted the hybridZadurella F1, an early hybrid, with undetermined growth, recommended for protected areas (www.agrobro.ro). The planting took place on 09.05.2020 and 12.03.2020, respectively.Were kept 7 fruit sets (farmer 1 ) and 8 fruit sets (farmer 2).

The traps were placed in tomato crops on 20.05.2020. In the case of the first farmer (Dobreni), on the same day, the first chemical control treatment was applied. During the experiment, 8 treatments were applied, at 7 daysintervals, with several control products, alternatively, as follows: Coragen $0.0175 \%$, Alverde $0.1 \%$, Affirm $0.15 \%$, Benevia $0.0125 \%$, Laser 240 SC $0.05 \%$, Coragen $0.0175 \%$, Benevia $0.0125 \%$ and VoliamTargo $0.08 \%$. 9 treatments were applied to the second farmer (Vărăști), at 7 daysintervals, as follows: Alverde $0.1 \%$, Coragen $0.0175 \%$, Affirm 0.15\%, VoliamTargo $0.08 \%$, Laser 240 SC 0.05\%, Coragen $0.0175 \%$, Alverde $0.1 \%$, Laser 240 SC $0.05 \%$ and Affirm $0.15 \%$.

Pest monitoring was done weekly, by changing the sticky plates with pheromones from Delta traps, on the dates: 10.06, 17.06, 24.06, 01.07, 08.07, 15.07 at the first farmer and, respectively, $03.06,10.06,17.06,24.06,01.07,08.07,15.07$ to the second farmer. Dynamic observations were made on the frequency and intensity of the pest attack, finally calculating, according to the Abbot's formula, the degree of attack on the leaves. Yield was also recorded, reported at the end $/ \mathrm{m}^{2}$.

\section{RESULTS AND DISCUSSIONS}

On May 20, when the Delta traps were placed in the tomato crops, the pest was present on both high plastic tunnels of the 2 farmers, the attack being only on the leaves (fig. 1).

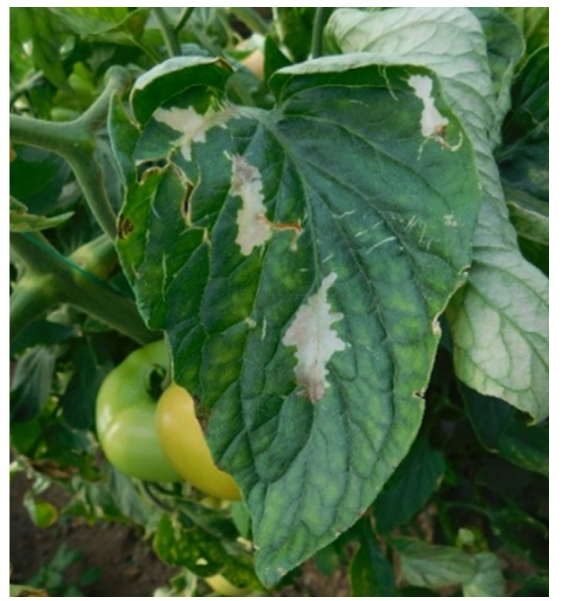

Figure 1. Tuta absoluta attack on tomato leaf

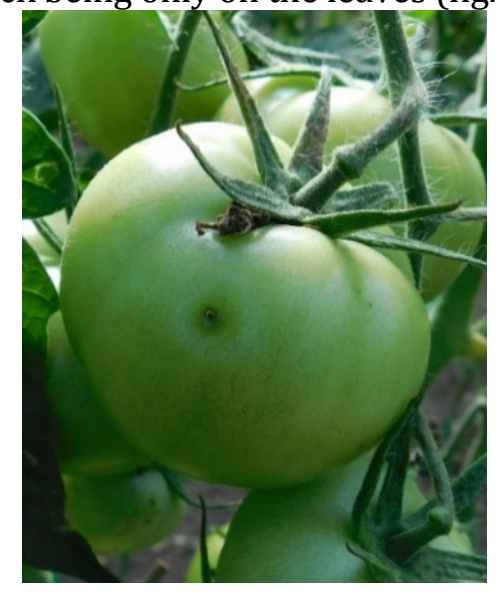

Figure 2. Tuta absoluta attack on tomato fruit 
At farmer 1, the attack on fruits (fig. 2) was registered on 01.07 (table 1), while on farmer 2 on 17.06 (table 2).

During the crop cycle, the sticky plates were replaced when their surface was full of captured adults.At the first farmer, their number varied between 52 and 482(fig. 3), with an average of 374 captured adults $/ 397.75 \mathrm{~cm}^{2}\left(94.0\right.$ adults $\left./ 100 \mathrm{~cm}^{2}\right)$.The degree of attack evolved from $0.3 \%(27.05)$ to $16.1 \%$ (22.07; table 1$)$.

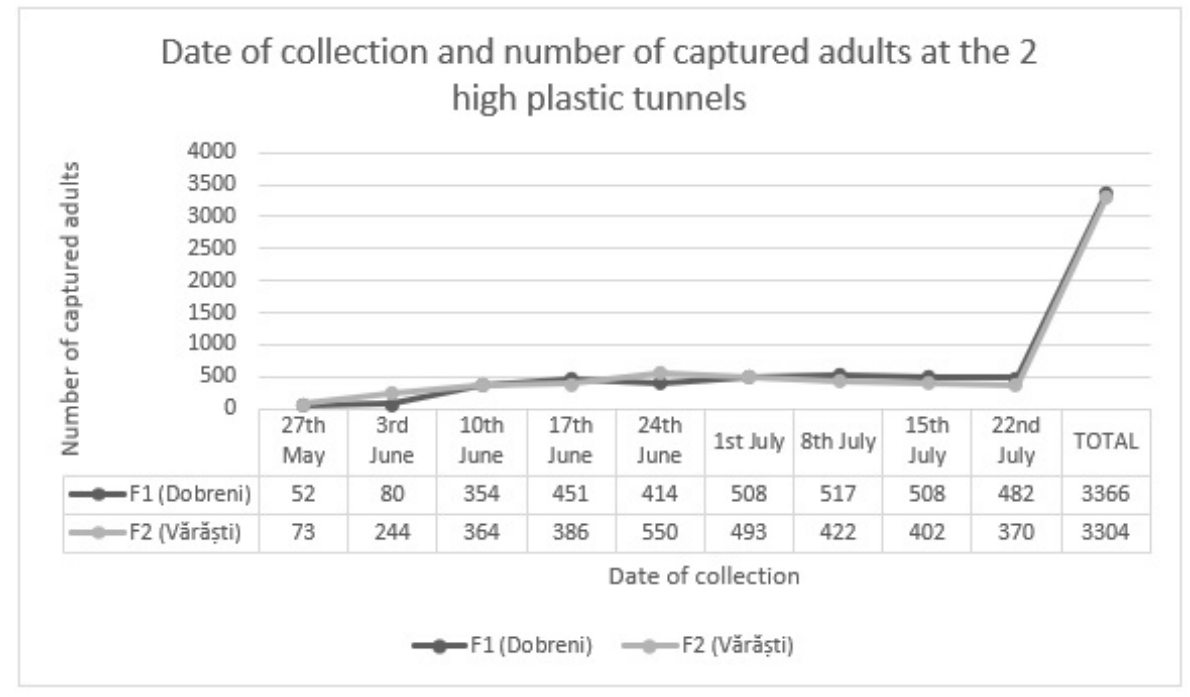

Figure 3. The date of collection of pheromone plates and the number of adults caught between May and July at the 2 high plastic tunnels

Table 1. Evolution of the attack of Tutaabsolutapeston tomato crop from the high plastic tunnel (farmer 1, Dobreni)

\begin{tabular}{|c|c|c|c|c|}
\hline \multirow[t]{2}{*}{$\begin{array}{l}\text { Date of } \\
\text { monitoring }\end{array}$} & \multicolumn{2}{|c|}{$\begin{array}{l}\text { Number of captured } \\
\text { adults }\end{array}$} & \multirow{2}{*}{$\begin{array}{c}\text { Degree of attack } \\
(\%)\end{array}$} & \multirow[t]{2}{*}{$\begin{array}{c}\text { Frequency of attacked fruits } \\
(\%)\end{array}$} \\
\hline & $\begin{array}{c}\text { on plate } \\
(397,75 \\
\left.\mathrm{cm}^{2}\right)\end{array}$ & $\begin{array}{c}\text { on } 100 \\
\mathrm{~cm}^{2}\end{array}$ & & \\
\hline 27.05 & 52 & 13.1 & 0.3 & 0 \\
\hline 03.06 & 80 & 20.1 & 0.7 & 0 \\
\hline 10.06 & 354 & 89.0 & 1.5 & 0 \\
\hline 17.06 & 451 & 113.4 & 1.7 & 0 \\
\hline 24.06 & 414 & 104.1 & 3.9 & 0 \\
\hline 01.07 & 508 & 127.7 & 5.4 & 1.1 \\
\hline 08.07 & 517 & 130.0 & 8.6 & 2.9 \\
\hline 15.07 & 508 & 127.7 & 11.8 & 5.9 \\
\hline 22.07 & 482 & 121.2 & 16.1 & 8.1 \\
\hline Average & 374 & 94.0 & 5.5 & 4.5 \\
\hline
\end{tabular}

At the second farmer, the number of adults varied between 73 and 370 (fig. 3), with an average of 367 captured adults/397.75 $\mathrm{cm}^{2}$ (92.3 adults $\left./ 100 \mathrm{~cm}^{2}\right)$. The degree of attack evolved from $0.2 \%$ (27.05) to $11.9 \%$ (22.07; table 2). 


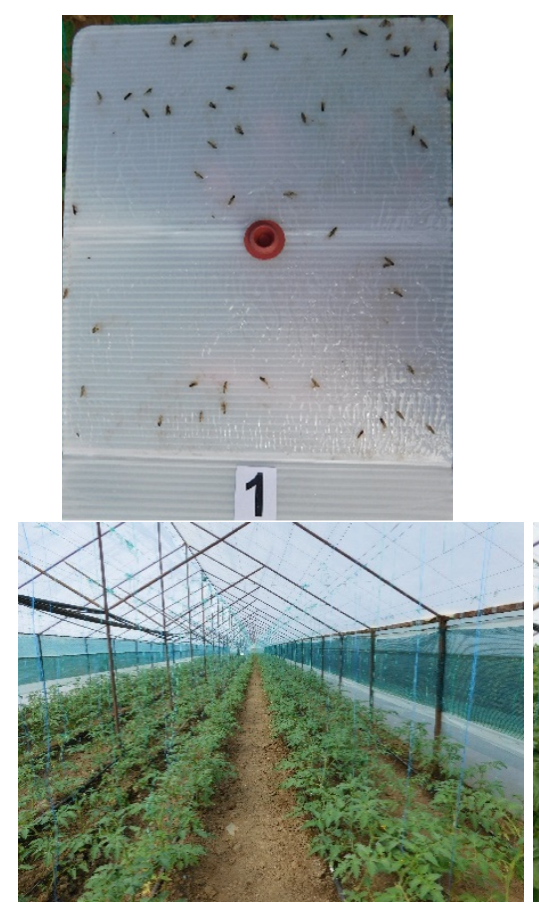

27.05

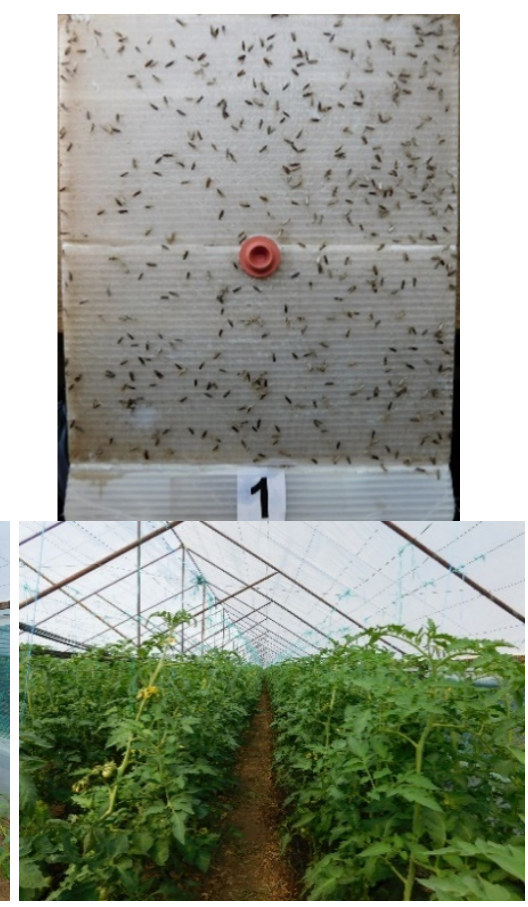

24.06

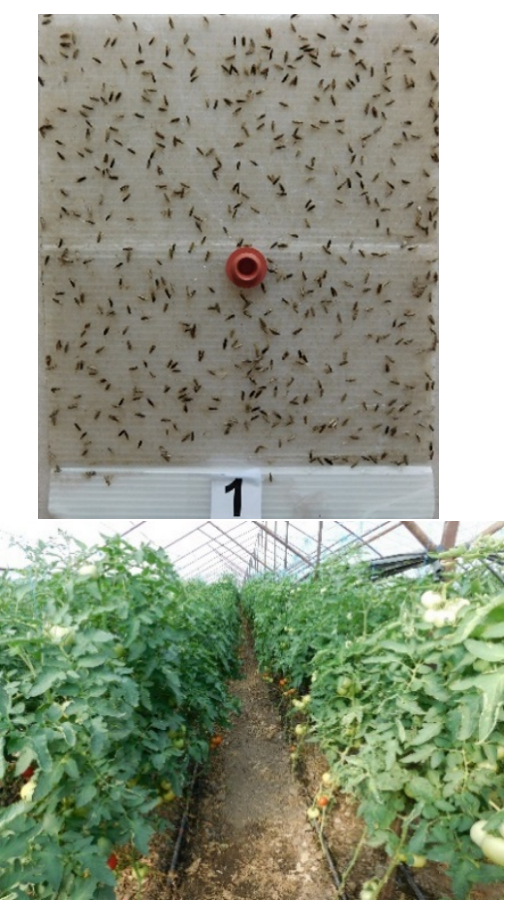

22.07

Figure 4. Sticky plates with captured adults and the crops aspect on 3 different dates $(27.05 ; 24.06 ; 22.07)$, at farmer 1

Based on the results obtained, at farmer 2 finds that the pest density was lower, and consequently the degree of attack was lower $(11.9 \%)$ than the first farmer $(16.1 \%)$. The average number of fruits attacked on the second farmer was lower (3.0\%) compared to the first farmer $(4.5 \%)$.

Towards at the end of the growing period, there was a decline in the number of adults caught on the sticky plates (tables 1 and 2), probably due to the migration of the pests to young plants, newly established in the crops from the second cycle.

Table 2. Evolution of the attack of Tutaabsoluta pest on the tomato crop from the high plastic tunnel (farmer 2, Vărăști)

\begin{tabular}{|c|c|c|c|c|}
\hline \multirow{2}{*}{$\begin{array}{c}\text { Date of } \\
\text { monitoring }\end{array}$} & \multicolumn{2}{|c|}{$\begin{array}{c}\text { Number of captured } \\
\text { adults }\end{array}$} & $\begin{array}{c}\text { Degree of attack } \\
(\%)\end{array}$ & $\begin{array}{c}\text { Frequency of attacked fruits } \\
\text { (\%) }\end{array}$ \\
\cline { 2 - 3 } & $\begin{array}{c}\text { on plate } \\
(397,75 \\
\left.\mathrm{cm}^{2}\right)\end{array}$ & $\begin{array}{c}\text { on } 100 \\
\mathrm{~cm}^{2}\end{array}$ & & \\
\hline 27.05 & 73 & 18.3 & 0.2 & 0 \\
\hline 03.06 & 244 & 61.3 & 1.3 & 0 \\
\hline 10.06 & 364 & 91.5 & 2.5 & 0.8 \\
\hline 17.06 & 386 & 97.0 & 3.2 & 1.3 \\
\hline 24.06 & 550 & 138.3 & 4.5 & 1.8 \\
\hline 01.07 & 493 & 123.9 & 5.8 & 3.2 \\
\hline 08.07 & 422 & 106.1 & 7.7 & 4.7 \\
\hline 15.07 & 402 & 101.1 & 9.1 & 6.2 \\
\hline 22.07 & 370 & 93.0 & 11.9 & 3.0 \\
\hline Average & 367 & 92.3 & 5.1 & \\
\hline
\end{tabular}




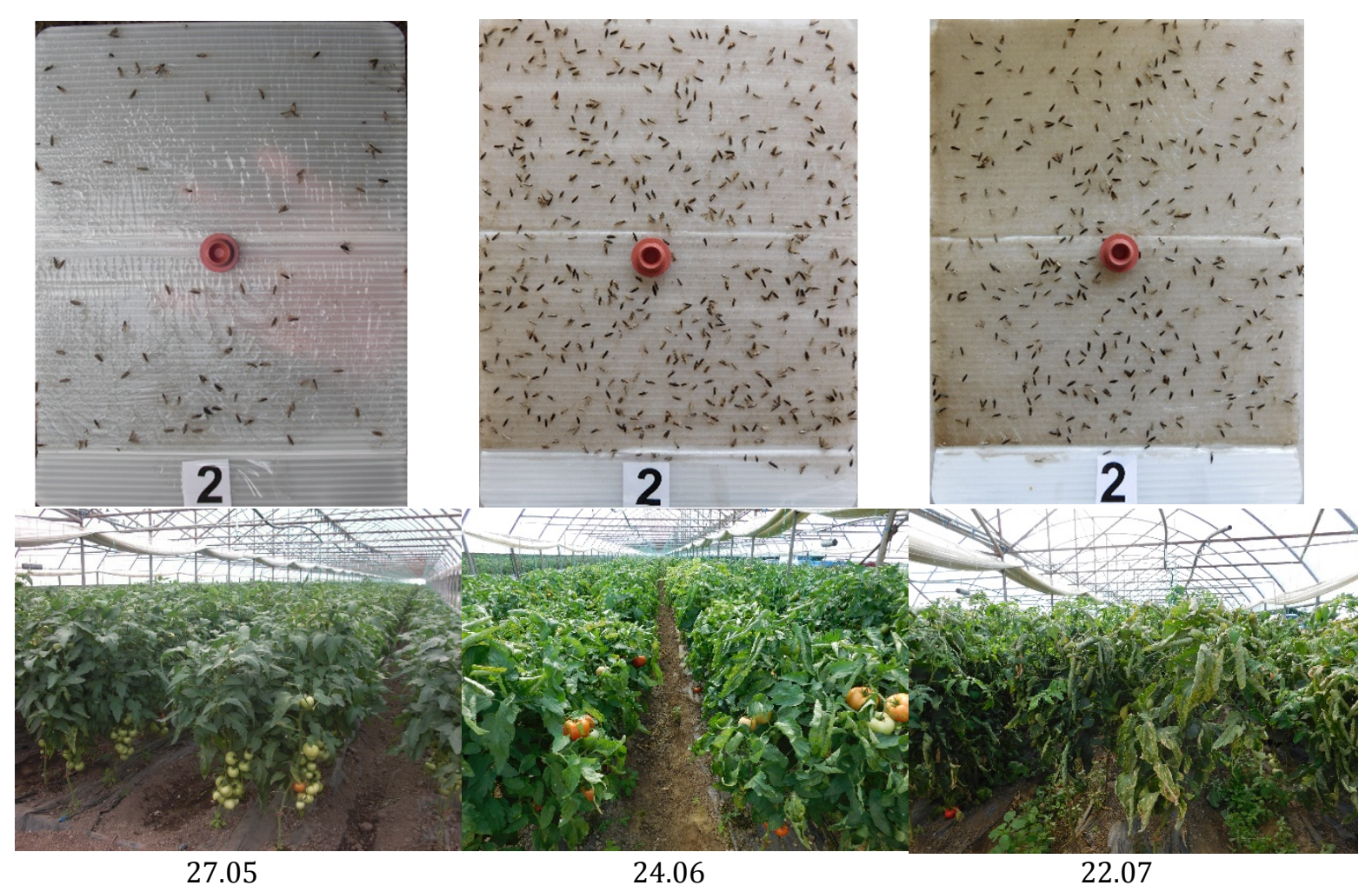

Figure 5. Sticky plates with captured adults and the crops aspect at 3 different dates (27.05; 24.06 ; 22.07) at farmer 2

In figures 4 and 5 is shown the aspect of tomato crops, from the 2 farmers, in different phenological phases during May-July and the sticky collector plates.

The yields obtained at the end of the growth period were $6,950 \mathrm{~kg} / \mathrm{m}^{2}(69.5 \mathrm{t} / \mathrm{ha})$ for farmer 1 and $8,270 \mathrm{~kg} / \mathrm{m}^{2}(82.7 \mathrm{t} / \mathrm{ha})$ for farmer 2 , respectively.

\section{CONCLUSIONS}

- $\quad$ Delta pheromone traps are especially useful for signaliging the appearance of the pest Tuta absoluta and monitoring the evolution of its attack on protected tomato crops, being an important decision-maker in the establishing the moment when must to start the treatments.

- $\quad$ At the same time, they contribute significantly to the decrease of pest populations in a certain habitat, by replacing them at the right time (depending on population density) and the use number of recomendedtrapsper unit area (3-4 traps/ha).

- $\quad$ Based on the results obtained in the experiments performed on 2 farmers, from Dobreni and Vărăști respectively, it can be concluded that, by using Delta pheromone traps and applying treatments with specific products to control this pest, at intervals dictated by the pest density (of 7 days), the pest populations can be kept under control, which provide to obtain constant and good quality tomato yields.

\section{ACKNOWLEDGEMENTS}

Work carried out within the Sectorial Plan for Rural Research-Development ADER 2020, financed by MADR, Project 7.3.15. "Establishing measures and means for integrated pest 
prevention and control Tuta absoluta, the mining moth in tomato crops in protected areas" (contract nr. 7.3.15/16.09.2019).

\section{REFERENCES}

1. Bratu, E., Petcuci, A.M., Sovarel, G. (2015). Efficacy of the Product Spinosad an Insecticide Used in the Control of Tomato Leafminer (Tutaabsoluta- Meyrick, 1917). BulletinUASVM Horticulture,72(1),DOI:10.15835/ buasvmcn-hort:10876

2. Cocco, A., Deliperi, S., Delrio. G. (2012). Control of Tutaabsoluta(Meyrick) (Lepidoptera: Gelechiidae) in greenhouse tomato crops using the mating disruption technique. J. Appl. Entomol., doi: 10.1111/j.14390418.2012.01735.x.

3. Mkonyi, L., Rubaga, D., Richard, M., Zekeya, N., Sawahiko, S., Maiseli, B., Machuve, D. (2020). Early identification of Tuta absoluta in tomato plants using deep learning. Scientific African 10, e00590

4. https://www.marcoser.ro/produse/seminte-de-legume/tomate/nedeterminate/sahmat-f1.html

5. https://agrobro.ro/product/1835/tomate-nedeterminate-zadurella-f1-v370-f1.html 